ELECTRONIC LETTER

\title{
Renoprotective efficacy of renin-angiotensin inhibitors in IgA nephropathy is influenced by ACE A2350G polymorphism
}

\author{
I Narita, S Goto, N Saito, J Song, K Omori, D Kondo, M Sakatsume, F Gejyo
}

J Med Genet 2003;40:e130 (http://www.jmedgenet.com/cgi/content/full/40/12/e130)

1 mmunoglobulin A nephropathy (IgAN) is the most prevalent form of primary glomerulonephritis and one of the principal causes of end stage renal disease (ESRD) throughout the world. ${ }^{12}$ It is a complex disease, in which familial clustering suggests an inherited genetic predisposition. The disease has a variable clinical course, and one third of patients with IgAN progress to ESRD within 10-20 years of its onset. ${ }^{3}$ The mechanisms of interindividual differences in the rate of disease progression are unclear. ${ }^{5}$

That increased production or activity of angiotensin II plays a detrimental role in the glomerular response to injury has been well documented. Recently, angiotensin converting enzyme (ACE) inhibitors and angiotensin receptor blocker (ARB) treatments have been shown to decrease proteinuria by improving glomerular permselectivity in $\operatorname{IgAN},{ }^{67}$ although the therapeutic effect was not recognised in about half of the patients.

An insertion/deletion (I/D) polymorphism of the angiotensin I converting enzyme gene has been shown to influence the concentration of ACE in the circulation and local tissues. ${ }^{8-10}$ Many studies have explored the association between the $A C E$ $\mathrm{I} / \mathrm{D}$ polymorphism and the development and progression of various cardiovascular diseases and renal diseases, including IgAN. ${ }^{11-13}$ Moreover, several studies have investigated associations between the ACE I/D polymorphism and the therapeutic efficacy of ACE inhibitors. The DD homozygote of the ACE I/D polymorphism has been reported as a risk factor for progression to ESRD in patients with IgAN, as well as a predictive marker for responsiveness to the antiproteinuric effects of ACE inhibitors. ${ }^{14}$ Other studies, however, reported that patients with the DD genotype were resistant to the renoprotective effects of ACE inhibitors, whether they had non-diabetic or diabetic nephropathy. ${ }^{15-17}$

Recently, an informative set of 13 single nucleotide polymorphisms (SNPs) across the entire ACE gene has been shown, and strong evidence from a large population based sample suggests that two SNPs-ACE A-240T and A2350Gare associated with plasma concentrations of ACE. ${ }^{18} \mathrm{~A}$ polymorphism in exon 17, ACE A2350G, had the most significant effect on the concentration of ACE, whereas, after the effect of $\mathrm{A} 2350 \mathrm{G}$ was adjusted for, the I/D polymorphism was not associated with the circulating concentration of ACE.

Taken together, it seems reasonable to hypothesise that these more functionally significant SNPs in the ACE gene may be involved in interindividual differences in the progression of glomerular injury. We investigated the possible role of these SNPs in the prognosis of renal function and on the therapeutic efficacy of ACE inhibitors and ARBs in patients with IgAN.

\section{MATERIALS AND METHODS} Participants

The ethics committee of the University Graduate School of Medical and Dental Sciences approved the protocol for the

\section{Key points}

- Individual variations in responsiveness to the antiproteinuric and renoprotective effects of angiotensin converting enzyme (ACE) inhibitors in patients with immunoglobulin A nephropathy (IgAN) have been suggested to be influenced by genetic background. An insertion and deletion (I/D) polymorphism of the ACE gene is the candidate proposed to date, although the results are controversial. Recent evidence from a large population based sample suggested that two single nucleotide polymorphisms, ACE A-240T and A2350G, are strongly associated with plasma concentrations of ACE.

- 267 patients with histologically proven IgAN (114 of whom received ACE inhibitors or angiotensin receptor blocker (ARB), or both during their clinical course), were investigated retrospectively for clinical manifestations and renal prognosis, and associations with genotypes of ACE A-240T, I/D, and A2350G polymorphisms were evaluated.

- Renal prognosis was significantly better in patients who received ACE inhibitor or ARB, even though they had higher blood pressures and values of proteinuria at diagnosis. Proteinuria (>1.0 g/day), hypertension, no treatment with $A C E$ inhibitor or $A R B$, and the $A A$ genotype of $A 2350 G$ were independent risk factors for progression of renal dysfunction; A-240T and I/D polymorphisms were not. The renoprotective effect of treatment with ACE inhibitor or ARB was remarkable in patients with the AA genotype (hazard ratio 7.473, $p<0.0001$ ), while the efficacy was not significant in those with other genotypes (1.767, $p=0.1119$ ).

- The ACE A2350G polymorphism may influence responsiveness to treatments that inhibit the reninangiotensin system with respect to long term prognosis of renal function in Japanese patients with lgAN.

genetic study. Japanese patients were eligible for inclusion in the analysis if they had been diagnosed as having IgAN by kidney biopsy at our institute between 1976 and 2001; had no evidence of systemic diseases such as hepatic glomerulo-

Abbreviations: $\lg \mathrm{AN}$, $\lg \mathrm{A}$ nephropathy; $\mathrm{ACE}$, angiotensin converting enzyme; ACEi, angiotensin converting enzyme inhibitor; ARB, angiotensin receptor blocker; $\mathrm{Cl}$, confidence interval; I/D, insertion and deletion 
Table 1 Clinical characteristics of patients with immunoglobulin A nephropathy. Values are mean (SD)

\begin{tabular}{|c|c|c|c|c|c|}
\hline \multirow[b]{2}{*}{ Characteristic } & \multirow[b]{2}{*}{$\begin{array}{l}\text { All patients } \\
(n=267)\end{array}$} & \multicolumn{2}{|l|}{ ACEi or ARB } & \multirow[b]{2}{*}{ p Value } & \multirow[b]{2}{*}{$\chi^{2}$} \\
\hline & & $\begin{array}{l}\text { Received } \\
(n=114)\end{array}$ & $\begin{array}{l}\text { Not received } \\
(n=153)\end{array}$ & & \\
\hline Age (year) & 37.0 (SD 13.5) & 39.3 (SD 13.8) & 35.3 (SD 13.0) & 0.0230 & \\
\hline Sex (male \%) & 46.1 & 48.2 & 44.4 & 0.5377 & 0.380 \\
\hline \multicolumn{6}{|l|}{ Urinary protein excretion } \\
\hline (g/day) & 1.35 (SD 1.34) & 1.51 (SD 1.29) & 1.21 (SD 1.37) & 0.0104 & \\
\hline Serum creatinine (mg/dl) & 1.00 (SD 0.62) & 0.93 (SD 0.32) & 1.05 (SD 0.78) & 0.7022 & \\
\hline $\begin{array}{l}\text { Creatinine clearance }(\mathrm{ml} / \mathrm{min}) \\
\text { Blood pressure }(\mathrm{mm} \mathrm{Ha})\end{array}$ & 89.2 (SD 33.5) & 90.4 (SD 30.6) & 88.2 (SD 35.6) & 0.4727 & \\
\hline $\begin{array}{l}\text { Systolic } \\
\text { Syll }\end{array}$ & 127.9 (SD 18.4) & 1) 131.1 (SD 18.2) & 125.4 (SD 18.3) & 0.0099 & \\
\hline Diastolic & 77.3 (SD 13.5) & 79.3 (SD 13.9) & 75.8 (SD 13.0) & 0.0562 & \\
\hline Incidence of hypertension (\%) & 36.8 & 46.0 & 29.7 & 0.0069 & 7.311 \\
\hline Observed period (month) & 91.7 (SD 67.6) & 93.7 (SD 62.8) & 92.0 (SD 62.2) & 0.3384 & \\
\hline Incidence of PRD (\%) & 31.1 & 18.0 & 40.5 & $<0.0001$ & 15.215 \\
\hline Glucocorticoid (\%) & 27.7 & 40.4 & 18.3 & $<0.0001$ & 15.574 \\
\hline ACEi or ARB (\%) & 42.7 & 100 & 0 & & \\
\hline \multicolumn{6}{|l|}{ Blood pressure $(\mathrm{mm} \mathrm{Hg})$} \\
\hline Systolic & 128.6 (SD 16.6) & 132.0 (SD 17.0) & 127.4 (SD 17.4) & 0.0774 & \\
\hline Diastolic & 77.6 (SD 11.7 ) & 80.7 (SD 11.8) & 76.8 (SD 12.4) & 0.1891 & \\
\hline
\end{tabular}

sclerosis, Schönlein-Henoch purpura, and rheumatoid arthritis; had been followed up in our institute; and gave written informed consent for genetic study. Among 4493 patients who underwent renal biopsy at our institute between 1976 and 2001, 557 were diagnosed as having IgAN. In total, 267 patients fulfilled the criteria for inclusion and were recruited to the study. In all cases, the diagnosis of IgAN was based on a kidney biopsy that showed the presence of dominant or codominant glomerular mesangial deposits of immunoglobulin A, as assessed by immunofluorescence.

\section{Clinical data and survival analysis}

We retrospectively collected clinical characteristics of the patients, including age, sex, office blood pressure, level of urinary protein excretion (g/day), duration of observation (months), serum creatinine $(\mathrm{mg} / \mathrm{dl})$, and 24 hour creatinine clearance $(\mathrm{ml} / \mathrm{min})$, from medical records. Hypertension was defined by the use of one or more antihypertensive drugs or blood pressure $\geqslant 140 \mathrm{~mm} \mathrm{Hg}$ (systolic) or $90 \mathrm{~mm} \mathrm{Hg}$ (diastolic), or both. In the survival analysis, the primary endpoint (progressive renal disease) was defined as the date at which the concentration of serum creatinine was double that at the time of diagnosis or when the patient underwent their first haemodialysis. All patients were treated according to our study group's standard protocol for patients with primary glomerulonephritis. Corticosteroids generally were administered to patients with a urinary protein excretion $>1.0 \mathrm{~g} /$ day at the time of renal biopsy, with the exception of cases with poor renal function ( 24 hour creatinine clearance $<30 \mathrm{ml} / \mathrm{min}$ ) and those aged $\geqslant 65$ years. Antihypertensive agents were given in combination with or without ACE inhibitor or ARB to maintain the blood pressure $<140 \mathrm{~mm} \mathrm{Hg}$ (systolic) and $<90 \mathrm{~mm} \mathrm{Hg}$ (diastolic). Administration of glucocorticoids, antihypertensive agents, ACE inhibitors, and ARBs also was recorded for each patient. In total, 114 patients received ACE inhibitors or ARBs, or both, after the diagnosis and during their clinical course. About half of the ACE inhibitors prescribed were enalapril (2.5-10 mg/day; 56 patients); other ACE inhibitors prescribed included temocapril ( $1-4 \mathrm{mg} /$ day; $\mathrm{n}=19)$, quinapril (5$10 \mathrm{mg} /$ day; $\mathrm{n}=16$ ), lisinopril $(5-10 \mathrm{mg} /$ day; $\mathrm{n}=8)$, captopril (25-37.5 mg/day; $\mathrm{n}=4$ ), and delapril (7.5-30 mg/day; $\mathrm{n}=3$ ). An $\mathrm{ARB}$ was prescribed in 36 patients: losartan
(25-50 mg/day) in 16 patients and candesartan (2-8 mg/day) in 20 patients; 28 patients were given an ACE inhibitor and an ARB.

\section{Determination of genotypes}

Genomic DNA from the peripheral blood cells was isolated with an automatic DNA isolation system (NA-1000; Kurabo, Osaka, Japan). The ACE I/D, A-240T, and A2350G genotypes of the patients were determined in a double blind manner. The I/D polymorphism in intron 16 of the ACE gene was assessed by polymerase chain reaction (PCR), as previously described. ${ }^{8}$ To avoid mistyping ID heterozygote as DD because of the preferential amplification of the D allele compared with the I allele, we amplified DNA from all participants with the DD genotype by using an I allele-specific primer (5'TTTGAGACGGGAGTCTCGCTC-3' $).{ }^{19}$ ACE A-240T and A2350G polymorphisms were assessed by allele specific PCR amplification. Fragments of DNA that contained the SNP region of the gene were amplified by PCR by using two allele specific primers and the biotin labelled antisense primers, or vice versa. The $5^{\prime}$-end of the allele specific primers was labelled with fluorescein isothiocyanate or Texas Red. For the A-240T polymorphism in the ACE gene, biotin-GTGGGCA GGCTCGGGTGTT-3' was used as the forward primer and fluorescein isothiocyanate-AAAGGGCCTCCTCTCTTCAG-3' and Texas Red-GAAAGGG CCTCCTCTCTTCTG-3' '- as the reverse primers. For the A2350G polymorphism, fluorescein isothiocyanate-GACGAATGTGATGGCCAAGT-3' and Texas Red-GACGAATGTGATGGCCAGAT-3' were used as the forward primers and biotin-TTGATGAGTTCCACGTATTTCG$3^{\prime}$ as the reverse primer. The second base from the $3^{\prime}$-end of each allele specific primer corresponded to the nucleotide of each allele, and the artificial mismatch nucleotide was inserted at the third base (indicated by underlines) to obtain maximum specificity. The reaction mixture $(25 \mu \mathrm{l})$ contained $0.02 \mu \mathrm{g}$ of DNA, $5 \mathrm{pmol}$ of each oligonucleotide primer, $0.2 \mathrm{mM}$ of each deoxynucleoside triphosphate, $2.5 \mathrm{mM}$ magnesium chloride, and 1 unit of DNA polymerase (rTaq; Toyobo, Osaka, Japan) in rTaq buffer. The amplification protocol consisted of an initial denaturation at $94^{\circ} \mathrm{C}$ for 5 minutes, 35 cycles of denaturation at $95^{\circ} \mathrm{C}$ for 30 seconds, annealing at $62.5^{\circ} \mathrm{C}$ for 30 seconds, an extension at $72^{\circ} \mathrm{C}$ for 30 seconds; and a final extension at $72^{\circ} \mathrm{C}$ for 2 minutes. 
Amplified DNA was mixed with streptoavidin conjugated magnetic beads in a 96 well plate, and after 15 minutes' incubation at room temperature, the magnetic beads were collected. The supernatant, which contained the primers not used in the PCR amplification, was taken out and placed into a new 96 well white plate that contained $0.01 \mathrm{~N}$ sodium hydroxide, and the samples were excited at $485 \mathrm{~nm}$ for fluorescein isothiocyanate and $584 \mathrm{~nm}$ for Texas Red. The fluorescence emissions for fluorescein isothiocyanate and Texas Red were measured with an automated chemiluminescent assay system (Toyobo).

\section{Statistical analysis}

We used $\chi^{2}$ analysis to compare allele frequencies and categorical variables between the groups. We compared continuous variables with the Mann-Whitney U-test or Kruskal-Wallis analysis of variance, and we tested the Hardy-Weinberg equilibrium by a $\chi^{2}$ test with one degree of freedom. We used the Kaplan-Meier method and Cox proportional hazards regression model to analyse the course from renal biopsy to endpoint. Variables that achieved statistical significance $(\mathrm{p}<0.05)$ in the univariate analysis subsequently were included in a multivariate analysis with a stepwise forward Cox regression procedure, and the effects of these covariates were expressed by a hazard ratio. Values of $\mathrm{p}<0.05$ were considered statistically significant. Haplotype analysis, which was based on a maximum likelihood method, was performed with Arlequin (version 2.0; University of Geneva, Geneva, Switzerland). Pairwise linkage disequilibrium coefficients were calculated and expressed as $\mathrm{D}^{\prime}=\mathrm{D} / \mathrm{D}$ max or $\mathrm{D} / \mathrm{D}$ min, according to Thompson et al. ${ }^{20}$

\section{RESULTS}

\section{Clinical characteristics of the patients}

Table 1 compares the clinical characteristics of patients who did and did not receive an ACE inhibitor or ARB. No differences were noted in sex, serum creatinine, or 24 hour creatinine clearance at the time of renal biopsy or duration of follow up between the groups. The age, amount of urinary protein excretion, and systolic blood pressure were significantly higher $(p=0.0230, p=0.0104$, and $p=0.0099$, respectively) in patients who received ACE inhibitors or ARBs compared with those who did not. As the choice of antihypertensive agents was not controlled but was left up to each doctor, ACE inhibitors and ARBs tended to be given to patients with high grade proteinuria. The incidence of hypertension at the time of renal biopsy was significantly higher in patients who received ACE inhibitors or ARBs $\left(x^{2}=7.311, \mathrm{p}=0.0069\right)$, and a larger number of the patients also received corticosteroid treatment $\left(x^{2}=15.574\right.$, $\mathrm{p}<0.0001)$. Although the patients who received ACE inhibitors and ARBs had more severe clinical markers for the progression of renal dysfunction, the incidence of progressive

Table 2 Genotype distributions and allele frequencies of polymorphisms of $A C E$

\begin{tabular}{lllllll}
\hline \multicolumn{7}{c}{ ACE polymorphism } \\
\cline { 2 - 7 } Variable & A-240T & & I/D & & A2350G \\
\hline Genotype & AA & 99 & II & 103 & AA & 87 \\
& AT & 128 & ID & 128 & AG & 142 \\
& TI & 40 & DD & 36 & GG & 38 \\
Allele & Total & 267 & & 267 & & 267 \\
& A & 0.610 & I & 0.625 & A & 0.592 \\
& T & 0.390 & D & 0.375 & G & 0.408 \\
\hline
\end{tabular}

Table 3 Estimated frequencies of haplotypes of ACE polymorphisms

\begin{tabular}{llll}
\hline Haplotype & & & \\
\cline { 1 - 3 } Locus -240 & Intron 16 & Locus 2350 & Frequency \\
\hline A & D & A & 0.0215 \\
A & D & G & 0.0020 \\
A & I & A & 0.5523 \\
A & I & G & 0.0347 \\
T & D & A & 0.0100 \\
T & D & G & 0.3415 \\
T & I & A & 0.0158 \\
T & I & G & 0.0226 \\
\hline
\end{tabular}

renal disease during the observation period was significantly lower than in patients who did not receive ACE inhibitors or ARBs $\left(x^{2}=15.215, \mathrm{p}<0.0001\right)$. During follow up, the mean blood pressure and percentage of cases with blood pressure $<140 / 90 \mathrm{~mm} \mathrm{Hg}$ was not different between the groups.

\section{Genotype, allele, and estimated haplotype frequencies of $A C E$}

Table 2 gives the genotype distributions and allele frequencies of the ACE A-240T, I/D, and A2350G polymorphisms in patients with IgAN. The expected frequency of the genotypes, under the assumption of the Hardy-Weinberg equilibrium, did not differ from the observed genotype frequencies, and the genotype distribution of the I/D polymorphism was consistent with previous reports for the Japanese population. $^{2122}$ Table 3 also shows estimated haplotype frequencies. The two most frequent haplotypes, A-I-A and T-D-G, complemented each other at all three loci and accounted for $89.6 \%$ of the total. These polymorphisms were in tight, but not complete, linkage disequilibrium. D' was 0.9017 between A-240T and I/D, 0.8957 between I/D and A2350G, and 0.8665 between A-240T and A2350G ( $p<0.0001$ in each pair).

\section{Effect of A2350G polymorphism of the ACE gene on clinical manifestations}

Table 4 compares clinical manifestations among each genotype of $A C E$ A2350G. The patients with the AA homozygote of the ACE A2350G polymorphism tended to have higher blood pressures and lower 24 hour creatinine clearance at the time of renal biopsy than those with heterozygotes or $G$ allele homozygotes. Moreover, the incidence of progressive renal disease was higher in patients with the AA genotype during follow up $\left(\chi^{2}=7.970\right.$, $\mathrm{p}=0.0053)$. No remarkable difference was noted between patients with the AG genotype and the GG genotype at baseline with respect to urinary protein excretion, serum creatinine, 24 hour creatinine clearance, blood pressure, and incidence of hypertension. In survival analyses, we compared patients with the AA genotype and those who were heterozygous or homozygous for the $G$ allele. No significant association was detected between the other ACE polymorphisms investigated (A-240T and I/D) and any clinical manifestations (data not shown).

\section{Risk factors for progression to progressive renal disease}

During follow up (mean 91.7 (SD 67.6) months), 83/267 (31.1\%) patients progressed to progressive renal disease, while a substantial proportion of the patients had stable renal function. As a time to event analysis is favoured if a substantial proportion of patients have stable or slowly declining renal function, we used the Cox hazard regression 
Table 4 Clinical manifestations in patients with immunoglobulin A nephropathy by genotype of ACE A2350G polymorphism. Values are mean (SD)

\begin{tabular}{|c|c|c|c|c|c|}
\hline \multirow[b]{2}{*}{ Clinical manifestations } & \multicolumn{3}{|c|}{ Genotype of ACE A2350G polymorphism } & \multirow[b]{2}{*}{ p Value } & \multirow[b]{2}{*}{$\chi^{2}$} \\
\hline & AA $(n=87)$ & AG $(n=142)$ & GG $(n=38)$ & & \\
\hline \multicolumn{6}{|l|}{ At the time of renal biopsy } \\
\hline Age (year) & 37.5 (SD 13.1) & 37.4 (SD 14.0) & 34.0 (SD 12.0) & 0.3838 & \\
\hline Sex (male \%) & 50.8 & 43.7 & 44.7 & 0.5863 & 1.068 \\
\hline Urinary protein excretion (g/day) & 1.47 (SD 1.32) & 1.29 (SD 1.41) & 1.26 (SD 1.07) & 0.3869 & \\
\hline Cases with urinary protein $>1.0 \mathrm{~g} /$ day $(\%)$ & $37.9-1$ & 36.6 & 34.2 & 0.4459 & 1.615 \\
\hline Serum creatinine $(\mathrm{mg} / \mathrm{dll})$ & 1.09 (SD 0.69) & 0.98 (SD 0.64) & 0.87 (SD 0.27) & 0.1176 & \\
\hline Creatinine clearance $(\mathrm{ml} / \mathrm{min})$ & 83.3 (SD 36.2) & 90.8 (SD 32.9) & 96.6 (SD 26.5) & 0.0247 & \\
\hline \multicolumn{6}{|l|}{ Blood pressure $(\mathrm{mm} \mathrm{Hg})$} \\
\hline Systolic & 131.1 (SD 18.8) & 127.2 (SD 18.5) & 123.4 (SD 16.2) & 0.0569 & \\
\hline Diastolic & 79.2 (SD 14.0) & 76.4 (SD 13.4) & 76.7 (SD 12.5) & 0.3615 & \\
\hline Incidence of hypertension (\%) & 47.1 & 31.9 & 31.6 & 0.0593 & 5.730 \\
\hline \multicolumn{6}{|l|}{ During observation } \\
\hline Observed period (months) & 93.7 (SD 62.8) & 89.2 (SD 68.1) & 96.4 (SD 77.5) & 0.6756 & \\
\hline Incidence of PRD (\%) & 42.5 & 26.4 & 21.6 & 0.0159 & 8.286 \\
\hline Glucocorticoid (\%) & 29.0 & 28.9 & 28.9 & 0.4105 & 1.781 \\
\hline ACEi or ARB (\%) & 37.9 & 43.7 & 50.0 & 0.4295 & 1.690 \\
\hline \multicolumn{6}{|l|}{ Blood pressure $(\mathrm{mm} \mathrm{Hg})$} \\
\hline Systolic & 132.0 (SD 17.0) & 127.2 (SD 16.5) & 126.0 (SD 15.2) & 0.0479 & \\
\hline Diastolic & 80.7 (SD 11.8) & 75.7 (SD 11.5) & 77.4 (SD 10.9) & 0.0147 & \\
\hline
\end{tabular}

model to investigate predictive risk factors for the progressive renal disease (table 4). In this analysis, a urinary protein excretion $>1.0 \mathrm{~g} /$ day, hypertension, no ACE inhibitor or ARB treatment, and the AA genotype of the ACE A2350G polymorphism were all identified as independent risk factors for progression to progressive renal disease. After we adjusted for other prognostic factors (urinary protein excretion $>1.0 \mathrm{~g} /$ day and hypertension), the risk of progressive renal disease was 3.1 times higher in patients who did not receive an ACE inhibitor or ARB than in those who did (hazard ratio 3.111 (95\% confidence interval 1.797 to 5.385$), \mathrm{p}<0.0001)$ and 1.8 times higher in patients with the AA genotype of $A C E$ A2350G than in those with other genotypes (hazard ratio 1.794 ( 1.112 to 2.894$), p=0.0166$ ). None of the other clinical covariates, including age, sex, corticosteroid therapy, and other antihypertensive drugs, was a significant risk factor in the univariate analysis (table 4). No other polymorphisms in the ACE gene examined (I/D and A-240T) showed any significant association with the risk of progressive renal disease. As the A2350G polymorphism was associated most significantly with the progression to progressive renal disease, the A2350G genotype was included in the multivariate analysis.

\section{Effect of ACE inhibitor, ARB, and ACE A2350G polymorphism on renal survival}

Figure 1A shows renal survival in patients with IgAN who did and did not receive an ACE inhibitor or ARB. The therapeutic efficacy of ACE inhibitor or ARB on long term renal survival was observed by Kaplan-Meier analysis. The mean survivals of renal function in patients who did and did not receive an ACE inhibitor or ARB were 197.7 (SD 11.4) and 138.3 (SD 6.7) months, respectively (Figure 1A, Kaplan-Meier, log rank test $\left.\chi^{2}=10.759, \mathrm{p}=0.0010\right)$. Figure $1 \mathrm{~B}$ shows that renal survival in patients with the AA genotype of ACE A2350G was worse than in patients with other genotypes, although this effect was marginal $\left(\log\right.$ rank test $\chi^{2}=4.538, p=0.0332$ ).

\section{Interaction of genotype and treatment with ACE inhibitor or ARB on renal survival}

We stratified patients according to the $A C E$ genotypes to investigate the interaction between the ACE A2350G genotype and the renoprotective effect of ACE inhibitors or ARBs, and we investigated the effect of ACE inhibitor or ARB on the long term survival of renal function within each genotype. Renal survival within patients with the AA genotype of the ACE A2350G polymorphism was improved significantly by administration of ACE inhibitor or ARB (Figure 2A, log rank test $\left.\chi^{2}=11.150, p=0.0008\right)$, while this effect was not statistically significant in patients with the AG or GG genotypes (Figure 2B, log rank test $\chi^{2}=2.266, p=0.1322$ ). This was confirmed further by the Cox proportional hazard analysis performed on patients with each genotype (table 5). In patients with the AA genotype, no treatment of ACE inhibitor or ARB was a significant risk factor for progressive renal disease (hazard ratio 7.473 (2.899 to 19.265),

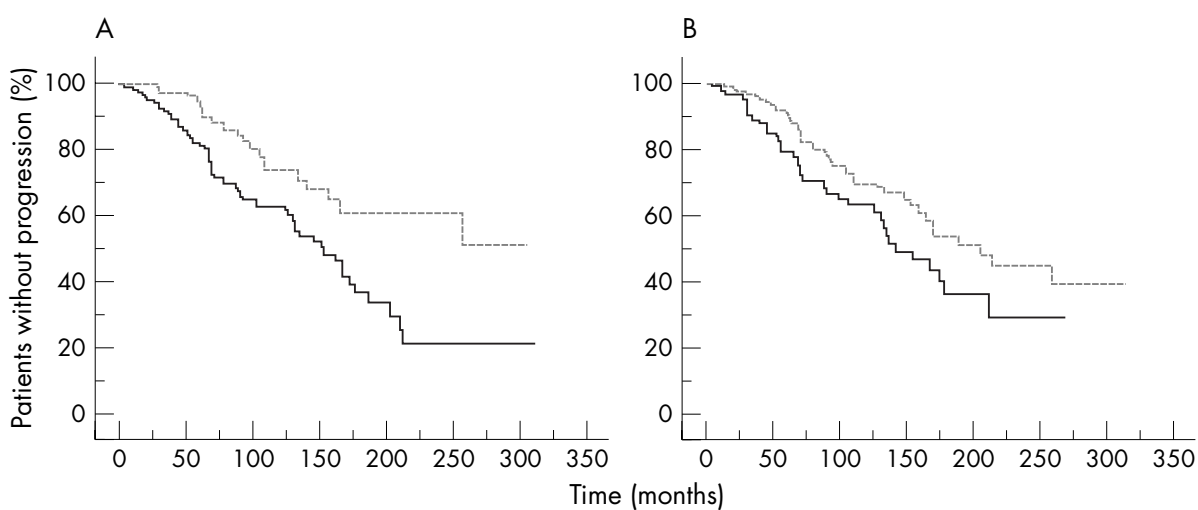

Figure 1 Renal survival in patients with IgAN who did $(n=114)$ or did not receive treatment with $A C E$ inhibitor or ARB $(n=153)$ (Kaplan-Meier log rank test, $p=0.0010$ ) (A) and in patients with $\lg A N$ with the $A G / G G$ genotype $(n=180)$ or $A A$ genotype $(n=87)$ of the ACE A2350G polymorphism who did receive treatment with ACE inhibitor or ARB (Kaplan-Meier log rank test, $\mathrm{p}=0.0332)(B)$. 


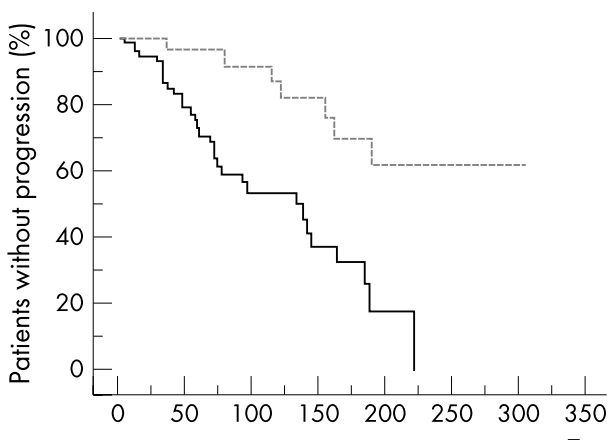

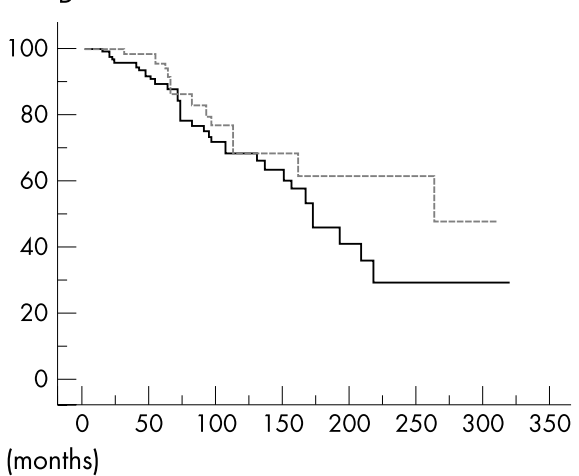

Figure 2 Renal survival curve for patients with $\lg \mathrm{AN}$ with the AA genotype of ACE A2350G polymorphism that compares patients who did $(n=33)$ and did not receive treatment with ACE inhibitor or ARB $(\mathrm{n}=54)$ (Kaplan-Meier log rank test $p=0.0008)(A)$ and renal survival curve for patients with $\lg A N$ and the $A G / G G$ genotype of ACE A2350G

polymorphism that compares patients who did $(n=81)$ and did not receive treatment with ACE inhibitor or ARB $(n=99)$ (Kaplan-Meier log rank test,

Time (months)

$\mathrm{p}<0.0001$ ), whereas this risk factor was not significant in those with other genotypes (1.767 (0.876 to 3.567), $\mathrm{p}=0.1119$ ).

\section{DISCUSSION}

This study showed the therapeutic efficacy of inhibition of the renin-angiotensin system on the long term prognosis of renal function in IgAN independently of blood pressure control. The genetic polymorphisms of ACE A-240T and I/D were not associated with the renal prognosis, while A2350G was associated marginally. Many studies have reported conflicting results about the association between the $A C E$ I/D polymorphism and renal prognosis in IgAN. ${ }^{13}$ Although the effects of A-240T and A2350G polymorphisms in IgAN have not been investigated previously, the present data were in accordance with results from a large scale study on a

Table 5 Cox proportional hazard model to test significance of clinical covariates and genotypes of ACE polymorphisms as predictors of renal survival

\begin{tabular}{|c|c|c|}
\hline Variable & p Value & $\begin{array}{l}\text { Hazard ratio } \\
(95 \% \mathrm{CI})\end{array}$ \\
\hline \multicolumn{3}{|l|}{ Univariate analysis } \\
\hline $\begin{array}{l}\text { Urinary protein excretion } \\
>1.0 \mathrm{~g} / \text { day }\end{array}$ & $<0.0001$ & 2.961 (1.719 to 5.101$)$ \\
\hline Hypertension & 0.0014 & 2.102 (1.334 to 3.312$)$ \\
\hline $\begin{array}{l}\text { No administration of } \\
\text { ACEi or ARB }\end{array}$ & 0.0014 & 2.281 (1.373 to 3.789$)$ \\
\hline No glucocorticoid therapy & 0.4817 & 0.831 (0.496 to 1.393$)$ \\
\hline Age & 0.1023 & $1.015(0.997$ to 1.033$)$ \\
\hline Sex (male) & 0.8028 & $1.057(0.682$ to 1.639$)$ \\
\hline \multicolumn{3}{|l|}{ Genotype } \\
\hline \multicolumn{3}{|l|}{ ACE A2350G } \\
\hline GG & Referent & 1 \\
\hline$A G$ & 0.4277 & $1.363(0.634$ to 2.931$)$ \\
\hline AA & 0.0352 & $1.599(1.033$ to 2.475$)$ \\
\hline \multicolumn{3}{|l|}{ ACE A-240T } \\
\hline$\pi$ & Referent & 1 \\
\hline AT & 0.5490 & $1.239(0.614$ to 2.500$)$ \\
\hline AA & 0.2755 & $1.479(0.732$ to 2.987$)$ \\
\hline \multicolumn{3}{|l|}{$A C E$ I/D } \\
\hline \| & Referent & 1 \\
\hline ID & 0.4007 & $0.732(0.354$ to 1.514$)$ \\
\hline DD & 0.5332 & $1.163(0.504$ to 2.680$)$ \\
\hline \multicolumn{3}{|l|}{ Multivariate analysis } \\
\hline $\begin{array}{l}\text { Urinary protein } \\
\text { excretion }>1.0 \mathrm{~g} / \text { day }\end{array}$ & $<0.0001$ & 3.102 (1.771 to 5.433$)$ \\
\hline Hypertension & 0.0002 & 2.509 ( 1.537 to 4.097 ) \\
\hline $\begin{array}{l}\text { No administration } \\
\text { of } A C E i \text { or } A R B\end{array}$ & $<0.0001$ & 3.111 (1.797 to 5.385$)$ \\
\hline $\begin{array}{l}\text { AA genotype of } A C E \\
\text { A2350G }\end{array}$ & 0.0166 & 1.794 (1.112 to 2.894$)$ \\
\hline
\end{tabular}

$A C E i$, angiotensin I converting enzyme inhibitor; $A R B$, angiotensin receptor blocker; $\mathrm{Cl}$, confidence interval.
Japanese population, which reported that the I/D polymorphism had no significant impact on the renal prognosis of IgAN. ${ }^{22}$ The effect of the A2350G polymorphism on renal survival was statistically significant, but it was marginal compared with the strong impact of other clinical risk factors such as proteinuria, hypertension, and no treatment with ACE inhibitor or ARB.

The therapeutic efficacy of ACE inhibitors or ARBs on the long term prognosis of renal function was remarkable in patients with the AA genotype, but not in those with other genotypes of the ACE gene A2350G polymorphism.

To be able to predict the renoprotective effects of antihypertensive agents for individual patients with renal disease is important. Although it already has been reported that the DD genotype of the I/D polymorphism in the $A C E$ gene is associated with the therapeutic efficacy of ACE inhibitors on proteinuria over a relatively short period of observation in patients with IgAN and diabetic nephropathy, ${ }^{1423}$ other studies have reported an opposite association in patients with diabetic and non-diabetic renal disease. ${ }^{15-17} 24$ In the present study, whether the effect of ACE inhibitors and ARBs on long term renal survival (rather than on proteinuria) was affected by the $A C E$ genotypes was evaluated, as this would have more important clinical implications and because consistent measurements of urinary protein excretion were not always available for each participant. In fact, we sometimes experienced fluctuations in urinary protein excretion of up to $50 \%$ or more, even in patients who had stable renal functions over a long time.

We could not completely deny the possibility that the observed renoprotective efficacy of ACE inhibitors and ARBs was secondary to the effect of corticosteroid therapy, because a larger proportion of patients was treated with corticosteroids in the group who received treatment with ACE inhibitors and ARBs. Although the efficacy of steroids on long term renal function is still a matter of controversy, its antiproteinuric effect has been confirmed by multiple randomised trials. $^{25-27}$ This study also could not detect an independent therapeutic effect of steroids on long term renal survival, and the results of the Cox proportional hazard regression analysis show that the efficacy of ACE inhibitors and ARBs was independent of steroid therapy. Moreover, the proportion of patients treated with corticosteroids, as well as those who received ACE inhibitors and ARBs was, at least, no different among groups with each genotype of the ACE A2350G polymorphism (table 3 ). This strongly suggests that differences in efficacy between genotype groups are not due to the effect of steroids.

Patients who received ACE inhibitors and ARBs had more proteinuria and a higher incidence of hypertension at the time of renal biopsy, which suggests that a substantial difference in the histological changes between the subgroups 
Table 6 Significance of clinical covariates for patients with AA or with AG or GG genotype of ACE A2350G polymorphism by Cox proportional hazard model

\begin{tabular}{|c|c|c|}
\hline Covariate & $\mathrm{p}$ Value & Hazard ratio $(95 \% \mathrm{Cl})$ \\
\hline \multicolumn{3}{|l|}{$\begin{array}{l}\text { Patients with the AA } \\
\text { genotype of } A C E A 2350 G\end{array}$} \\
\hline $\begin{array}{l}\text { Urinary protein } \\
\text { excretion }>1.0 \mathrm{~g} / \text { day }\end{array}$ & 0.0147 & 2.620 (1.209 to 5.680$)$ \\
\hline $\begin{array}{l}\text { Hypertension } \\
\text { No administration } \\
\text { of ACEi or ARB }\end{array}$ & $\begin{array}{l}0.0007 \\
<0.0001\end{array}$ & $\begin{array}{l}3.846(1.766 \text { to } 8.377) \\
7.473(2.899 \text { to } 19.265)\end{array}$ \\
\hline \multicolumn{3}{|l|}{$\begin{array}{l}\text { Patients with the } A G \text { or } G G \\
\text { genotype of } A C E A 2350 G\end{array}$} \\
\hline $\begin{array}{l}\text { Urinary protein } \\
\text { excretion }>1.0 \mathrm{~g} / \text { day }\end{array}$ & 0.0059 & 3.307 (1.412 to 7.743$)$ \\
\hline Hypertension & 0.0120 & 2.381 (1.210 to 4.689$)$ \\
\hline $\begin{array}{l}\text { No administration } \\
\text { of } A C E i \text { or } A R B\end{array}$ & 0.1119 & 1.767 (0.876 to 3.567$)$ \\
\hline
\end{tabular}

$\mathrm{Cl}$, confidence interval; $\mathrm{ACEi}$, angiotensin I converting enzyme inhibitor; $A R B$, angiotensin receptor blocker.

with or without treatment with ACE inhibitors and ARBs may be detected.

The main purpose of this study was to investigate the possible role of the $A C E$ gene polymorphisms in the prognosis of renal function and their interactions with efficacy of treatment with ACE inhibitors and ARBs. We chose covariates from clinical manifestations rather than histological changes to identify the prognostic factors. Histological changes correlate strongly with clinical findings, so the interaction between clinical and histological manifestations would reduce substantially their statistical significances in the multivariate analysis. Moreover, histological findings are much more complex and difficult to quantify and evaluate accurately.

Angiotensin converting enzyme inhibitors are currently the best documented inhibitors of the renin-angiotensin system and are reported to be renoprotective in diabetic and nondiabetic renal disease. ${ }^{78}$ Angiotensin receptor blockers are the other inhibitors of the renin-angiotensin system and have pharmacological properties distinct from those of the ACE inhibitors. We are not aware of any comparisons of the long term renoprotective effects of ACE inhibitors and ARBs, or a combination of both. ${ }^{7}$ Direct comparisons of the renal haemodynamic effects in patients with hypertension or renal diseases gave similar renal vasodilations in both classes of drugs. $^{29}{ }^{30}$ In small studies of patients with IgAN, the combination of ARB and ACE inhibitor was at least additive in decreasing protein excretion, ${ }^{31}{ }^{32}$ whereas the results of larger trials still are controversial. ${ }^{33}$ The numbers of participants who were treated with each drug were not large enough to analyse the data separately in the present study. Moreover, we could not completely deny the possibility of some bias as a result of this being a retrospective study. The tendency to use ACE inhibitor or ARB treatment in patients with glomerular diseases has grown stronger during the last decade. The duration of observation was not different between patients who did or did not receive ACE inhibitor or ARB, however, and patients who received treatment with ACE inhibitor or ARB were rather older than those who did not. Major potential clinical risk factors for progression of renal dysfunction, including no treatment with ACE inhibitor or ARB (which is assumed to be associated with chronologically older patients), were included as covariates in the Cox proportional hazard regression model. In addition, although other classes of antihypertensive drugs, such as diuretics, did not have any independent effect on the renal prognosis (data not shown), they may interact with the efficacy of ACE inhibitors or ARBs. Nonetheless, to confirm the results of the present study, a randomised, controlled, prospective study with a large scale population of patients on a fixed medication protocol is needed. To draw conclusions about the long term renal survival of patients with IgAN in a prospective study is difficult, because the actual prognosis of renal function in each case can only be determined after a long observation period. In fact, a substantial proportion of our patients had stable renal function, and only one third of them progressed to progressive renal disease during the mean observation period of 91.7 months. Even if the bias as a result of the retrospective nature of the study is taken into account, therefore, we believe that the Cox hazard regression model and time to event analysis with the past precise medical records is an adequate and feasible method for investigating the long term renal prognosis.

Another limitation of this study is that the association of the genotype and local activity or concentration of ACE was not provided. Although we have no data to investigate the association between $A C E$ genotypes and circulating concentrations of ACE in our patients, the G allele at the A2350G polymorphism was associated most strongly with an increased concentration of ACE. ${ }^{18}$ In addition, evidence for a linkage disequilibrium between the I/D and A2350G polymorphism in the $A C E$ gene has been found, ${ }^{35}$ although, as mentioned above, previous studies have produced conflicting evidence for the relation between genotype and therapeutic efficacy of ACE inhibitors. When we consider the strong linkage disequilibrium between I/D and A2350G loci, our results may support the results of van Essen et al and Parving et al and indicate that patients who have less circulating ACE tend to respond well to therapy with ACE inhibition in terms of glomerular injury. ${ }^{15}{ }^{16}$ At present, we have no data to explain the mechanism for the apparent dissociation between the genetic influence on concentrations of ACE on one hand and the response to ACE inhibition on the other. One possible explanation is that serum concentrations of ACE in healthy people may not necessarily reflect enhanced activity of ACE in local tissue, in particular of glomerular inflammatory injury. A second possibility is that the effect of the ACE genotype occurs through a mechanism other than its effect on serum concentrations of ACE. In support of this hypothesis is the finding from the EURODIAB controlled trial of lisinopril in insulin dependent diabetes that ACE inhibitors also have a beneficial effect on diabetic retinopathy, ${ }^{36}$ even though retinopathy, unlikely nephropathy, is not associated with elevated concentrations of ACE. ${ }^{37} 38$ As indicated by Ueda et al, ${ }^{39}$ in pragmatic terms, relatively low doses of drugs that inhibit the renin-angiotensin system may be enough for patients with low concentrations of ACE and low levels of angiotensin II, but not enough for full and sustained inhibition in those with high concentrations of ACE.

Pairwise linkage disequilibrium between polymorphic loci in this gene and magnitude of the association between these markers and circulating concentrations of ACE have been reported to vary according to ethnicity, ${ }^{40}$ whether the effect of the genetic variant investigated in this study is observed in other ethnic groups remains to be seen.

\section{Conclusion}

Polymorphisms in the ACE gene may be a significant genetic marker for predicting the renoprotective efficacy of reninangiotensin inhibition on long term renal prognosis in Japanese patients with IgAN. Although patients with the AA genotype of the A2350G polymorphism may be at a higher risk for progressive renal dysfunction in the absence of treatment with ACE inhibitors or ARBs, they may also have a greater response to inhibition of the renin-angiotensin 
system in terms of long term prognosis of renal function. These findings, if confirmed, may have important implications for clinical care, because ACE inhibitors and ARBs could be given more positively to patients with IgAN and the AA genotype at an early stage of the disease. Further study is needed to confirm our findings and to assess whether patients with the AG/GG genotype respond to high doses of inhibitors of the renin-angiotensin system.

\section{ACKNOWLEDGMENTS}

This work was supported in part by a health and labour science research grant for research on specific diseases from the Ministry of Health, Labour and Welfare and by a grant in aid for scientific research (C, No. 11671032) from the Ministry of Education, Culture, Sports, Science and Technology of Japan. We thank Naofumi Imai, Keiko Yamagiwa, and Kumiko Furui for excellent technical assistance.

\section{Authors' affiliations \\ I Narita, S Goto, N Saito, J Song, K Omori, D Kondo, M Sakatsume, F Gejyo, Division of Clinical Nephrology and Rheumatology, Niigata University Graduate School of Medical and Dental Sciences, Niigata, Japan}

Declaration of interest: none declared.

Correspondence to: Dr I Narita, Division of Clinical Nephrology and Rheumatology, Niigata University Graduate School of Medical and Dental Sciences, 757, Asahimachi-dori, Niigata, 951-8510, Japan; naritai@med.niigata-u.ac.jp

29 January 2003

26 June 2003

\section{REFERENCES}

1 D'Amico G. The commonest glomerulonephritis in the world: $\lg A$ nephropathy. Q J Med 1987:64:709-27.

2 Maisonneuve $P$, Agodoa L, Gellert R, Stewart JH, Buccianti G, Lowenfels AB Wolfe RA, Jones E, Disney AP, Briggs D, McCredie M, Boyle P. Distribution of primary renal diseases leading to end-stage renal failure in the United States, Europe, and Australia/New Zealand: results from an international comparative study. Am J Kidney Dis 2000;35:157-65.

3 Koyama A, Igarashi M, Kobayashi M. Natural history and risk factors for immunoglobulin A nephropathy in Japan. Research Group on Progressive Renal Diseases. Am J Kidney Dis 1997;29:526-32.

4 Szeto CC Lai FM, To KF, Wong TY, Chow KM Choi PC, Lui SF, Li PK. The natural history of immunoglobulin A nephropathy among patients with hematuria and minimal proteinuria. Am J Med 2001;110:434-7.

5 Rantala I, Mustonen J, Hurme M, Syrjanen J, Helin H. Pathogenetic aspects of IgA nephropathy. Nephron 2001;88:193-8.

6 Woo KT, Lau YK, Wong KS, Chiang GS. ACEI/ATRA therapy decreases proteinuria by improving glomerular permselectivity in $\lg A$ nephritis. Kidney Int 2000;58:2485-91.

7 Hilgers KF, Mann JF. ACE Inhibitors versus AT(1) receptor antagonists in patients with chronic renal disease. J Am Soc Nephrol 2002;13:1100-8.

8 Rigat B, Hubert C, Alhenc-Gelas F, Cambien F, Corvol P, Soubrier F. An insertion/deletion polymorphism in the angiotensin I-converting enzyme gene accounting for half the variance of serum enzyme levels. J Clin Invest 1990:86:1343-6.

9 Tiret L, Rigat B, Visvikis S, Breda C, Corvol P, Cambien F, Soubrier F. Evidence, from combined segregation and linkage analysis, that a variant of the angiotensin I-converting enzyme (ACE) gene controls plasma ACE levels. Am J Hum Genet 1992:51:197-205.

10 Costerousse O, Allegrini J, Lopez M, Alhenc-Gelas F. Angiotensin Iconverting enzyme in human circulating mononuclear cells: genetic polymorphism of expression in T-lymphocytes. Biochem $J$ 1993;290:33-40

11 O'Donnell CJ, Lindpaintner K, Larson MG, Rao VS, Ordovas JM, Schaefer EJ, Myers RH, Levy D. Evidence for association and genetic linkage of the angiotensin-converting enzyme locus with hypertension and blood pressure in men but not women in the Framingham Heart Study. Circulation 1998:97:1766-72.

12 Oike Y, Hata A, Ogata Y, Numata Y, Shido K, Kondo K. Angiotensin converting enzyme as a genetic risk factor for coronary artery spasm. Implication in the pathogenesis of myocardial infarction. J Clin Invest 1995;96:2975-9.

13 Hsu SI, Ramirez SB, Winn MP, Bonventre JV, Owen WF. Evidence for genetic factors in the development and progression of $\lg A$ nephropathy. Kidney Int 2000;57:1818-35.

14 Yoshida H, Mitarai T, Kawamura T, Kitajima T, Miyazaki Y, Nagasawa R, Kawaguchi $Y$, Kubo $H$, Ichikawa I, Sakai $O$. Role of the deletion of polymorphism of the angiotensin converting enzyme gene in the progression and therapeutic responsiveness of $\lg \mathrm{A}$ nephropathy. J Clin Invest 1995;96:2162-9.

15 van Essen GG, Rensma PL, de Zeeuw D, Sluiter WJ, Scheffer H, Apperloo AJ, de Jong PE. Association between angiotensin-converting-enzyme gene polymorphism and failure of renoprotective therapy. Lancet 1996;347:94-5.

16 Parving HH, Jacobsen P, Tarnow L, Rossing P, Lecerf L, Poirier O, Cambien F. Effect of deletion polymorphism of angiotensin converting enzyme gene on progression of diabetic nephropathy during inhibition of angiotensin converting enzyme: observational follow up study. BMJ 1996;313:591-4.

17 Penno G, Chaturvedi N, Talmud PJ, Cotroneo P, Manto A, Nannipieri M, Luong LA, Fuller JH. Effect of angiotensin-converting enzyme (ACE) gene polymorphism on progression of renal disease and the influence of ACE inhibition in IDDM patients: findings from the EUCLID Randomized Controlled Trial. EURODIAB Controlled Trial of Lisinopril in IDDM. Diabetes 1998;47:1507-11.

18 Zhu X, Bouzekri N, Southam L, Cooper RS, Adeyemo A, McKenzie CA, Luke A, Chen G, Elston RC, Ward R. Linkage and association analysis of angiotensin l-converting enzyme (ACE)-gene polymorphisms with ACE concentration and blood pressure. Am J Hum Genet 2001;68:1139-48.

19 O'Dell SD, Humphries SE, Day IN. Rapid methods for population-scale analysis for gene polymorphisms: the ACE gene as an example. Heart 1995;73:368-71.

20 Thompson EA, Deeb S, Walker D, Motulsky AG. The detection of linkage disequilibrium between closely linked markers: RFLPs at the AI-CIII apolipoprotein genes. Am J Hum Genet 1988:42:113-24.

21 Higaki J, Baba S, Katsuya T, Sato N, Ishikawa K, Mannami T, Ogata J, Ogihara T. Deletion allele of angiotensin-converting enzyme gene increases risk of essential hypertension in Japanese men: the Suita study. Circulation 2000;101:2060-5.

22 Suzuki S, Suzuki Y, Kobayashi Y, Harada T, Kawamura T, Yoshida H, Tomino Y. Insertion/deletion polymorphism in ACE gene is not associated with renal progression in Japanese patients with $\lg \mathrm{A}$ nephropathy. Am J Kidney Dis 2000;35:896-903.

23 Ha SK, Yong Lee S, Su Park H, Ho Shin J, Jung Kim S, Hun Kim D, Rae Kim K, Yung Lee $H$, Suk Han D. ACE DD genotype is more susceptible than ACE II and ID genotypes to the antiproteinuric effect of ACE inhibitors in patients with proteinuric non-insulin-dependent diabetes mellitus. Nephrol Dial Transplant 2000;15:1617-23

24 Jacobsen $P$, Rossing $K$, Rossing $P$, Tarnow L, Mallet $C$, Poirier $O$, Cambien $F$, Parving $\mathrm{HH}$. Angiotensin converting enzyme gene polymorphism and ACE inhibition in diabetic nephropathy. Kidney Int 1998;53:1002-6.

25 Pozzi C, Bolasco PG, Fogazzi GB, Andrulli S, Altieri P, Ponticelli C, Locatelli F. Corticosteroids in IgA nephropathy: a randomised controlled trial. Lancet 1999:353:883-7.

26 Lai KN, Lai FM, Ho CP, Chan KW. Corticosteroid therapy in IgA nephropathy with nephrotic syndrome: a long-term controlled trial. Clin Nephrol 1986;26: 174-80.

27 Shoii T, Nakanishi I, Suzuki A, Hayashi T, Togawa M, Okada N, Imai E, Hori M, Tsubakihara Y. Early treatment with corticosteroids ameliorates proteinuria, proliferative lesions, and mesangial phenotypic modulation in adult diffuse proliferative IgA nephropathy. Am J Kidney Dis 2000:35:194-201.

28 Lewis EJ, Hunsicker LG, Bain RP, Rohde RD. The effect of angiotensinconverting-enzyme inhibition on diabetic nephropathy. The Collaborative Study Group. N Engl J Med 1993;329:1456-62.

29 Gansevoort RT, de Zeeuw D, de Jong PE. Is the antiproteinuric effect of ACE inhibition mediated by interference in the renin-angiotensin system? Kidney Int 1994;45:861-7.

30 Gainer JV, Morrow JD, Loveland A, King DJ, Brown NJ. Effect of bradykininreceptor blockade on the response to angiotensin-converting-enzyme inhibitor in normotensive and hypertensive subjects. N Engl J Med 1998:339:1285-92

31 Russo D, Pisani A, Balletta MM, De Nicola L, Savino FA, Andreucci M Minutolo R. Additive antiproteinuric effect of converting enzyme inhibitor and losartan in normotensive patients with IgA nephropathy. Am J Kidney Dis 1999:33:851-6.

32 Russo D, Minutolo R, Pisani A, Esposito R, Signoriello G, Andreucci M, Balletta MM. Coadministration of losartan and enalapril exerts additive antiproteinuric effect in IgA nephropathy. Am J Kidney Dis $2001 ; 38: 18-25$.

33 Ruilope LM, Aldigier JC, Ponticelli C, Oddou-Stock P, Botteri F, Mann JF. Safety of the combination of valsartan and benazepril in patients with chronic renal disease. European Group for the Investigation of Valsartan in Chronic Renal Disease. J Hypertens 2000;18:89-95.

34 Mogensen CE, Neldam S, Tikkanen I, Oren S, Viskoper R, Watts RW Cooper ME. Randomised controlled trial of dual blockade of renin-angiotensin system in patients with hypertension, microalbuminuria, and non-insulin dependent diabetes: the candesartan and lisinopril microalbuminuria (CALM) study. BMJ 2000:321:1440-4.

35 Keavney B, McKenzie CA, Connell JM, Julier C, Ratcliffe PJ, Sobel E, Lathrop M, Farrall M. Measured haplotype analysis of the angiotensin-I converting enzyme gene. Hum Mol Genet 1998;7:1745-51

36 Chaturvedi N, Sjolie AK, Stephenson JM, Abrahamian H, Keipes M, Castellarin A, Rogulja-Pepeonik Z, Fuller JH. Effect of lisinopril on progression of retinopathy in normotensive people with type 1 diabetes. The EUCLID Study Group. EURODIAB Controlled Trial of Lisinopril in Insulin-Dependent Diabetes Mellitus. Lancet 1998;351:28-31.

37 Marre M, Bernadet P, Gallois Y, Savagner F, Guyene T, Hallab M, Cambien F, Passa P, Alhenc-Gelas F. Relationships between angiotensin I 
converting enzyme gene polymorphism, plasma levels, and diabetic retinal and renal complications. Diabetes 1994;43:384-8.

38 Tarnow L, Cambien F, Rossing P, Nielsen FS, Hansen BV, Lecerf L, Poirier O, Danilov $\mathrm{S}$, Parving $\mathrm{HH}$. Lack of relationship between an insertion/deletion polymorphism in the angiotensin I-converting enzyme gene and diabetic nephropathy and proliferative retinopathy in IDDM patients. Diabetes 1995;44:489-94.
39 Ueda S, Meredith PA, Morton JJ, Connell JM, Elliott HL. ACE (I/D) genotype as a predictor of the magnitude and duration of the response to an $A C E$ inhibitor drug (enalaprilat) in humans. Circulation 1998;98:2148-53.

40 McKenzie CA, Abecasis GR, Keavney B, Forrester T, Ratcliffe PJ, Julier C,

Connell JM, Bennett F, McFarlane-Anderson N, Lathrop M, Cardon LR. Transethnic fine mapping of a quantitative trait locus for circulating angiotensin Iconverting enzyme (ACE). Hum Mol Genet 2001; 10:1077-84. 